\title{
Upper cervical spine giant cell tumour of the vertebra - Case Report
}

\author{
Paweł Szmygin', Bartłomiej Kulesza', Cezary Grochowski', Jakub Litak', Witold Janusz' \\ ${ }^{1}$ Neurosurgery and Paediatric Neurosurgery Department, Clinical Hospital SPSK4, Lublin, Poland \\ Szmygin P, Kulesza B, Grochowski C, Litak J, Janusz W. Upper cervical spine giant cell tumour of the vertebra - Case Report. J Pre-Clin Clin \\ Res. 2016; 10(2): 133-135. doi: 10.5604/18982395.1227572
}

\begin{abstract}
Giant cell tumour (GCT) is a benign aggressive tumour, which affects the axial and peripheral skeleton. Pathological fractures often occur in cases where epiphyses are affected. GCT located in the cervical spine is rare and poses a serious surgical challenge and as far as approach and range of operation is concerned, is subject of debate. We report a case of GCT involving two vertebral bodies, C2 and C3, treated with posterior occipito-cervical junction stabilization, denosumab chemotherapy and transoral corpectomy.
\end{abstract}

\section{Key words}

giant cell tumour of the vertebrae, upper cervical spine region, denosumab therapy, occipito-cervical junction stabilization

\section{INTRODUCTION}

Giant cell tumour (GCT) of the spine is a rare entity and in the literature has been known as a benign aggressive tumour. It can affect mobile as well as rigid segments of the spine. in the mobile segment of spine the incidence of GCT is estimated to be $1.4-9.4 \%$ [1], with a slightly higher incidence among women. Most typically, the tumour occurs in the $3^{\text {rd }}$ or $4^{\text {th }}$ decade of life. $3 \%$ of patients with bone GCT of bones have metastases, most often to the lung [2]. The neoplasm affects the vertebral body, but can also affect posterior elements. Treatment of GCT consists in intralesional excision, en bloc spondylectomy, embolization, pharmacological management with denosumab and bisphosphonates.

\section{CASE REPORT}

In September 2014, the patient, a 25-year-old male, sought help from a general practitioner because of neck pain which he associated with a sprain due to work overload as a waiter in air-conditioned rooms. The physician initiated treatment with ointment, then a series of 5 analgetic injections, and finally physical therapy. Because of lack of improvement, increasing difficulties in holding his head upright, the patient was referred to a neurologist. Cervical spine X-ray was performed, in which the radiologist observed a decreased height in the height of the $\mathrm{C} 2 / \mathrm{C} 3$ intervertebral space. No pathological mass was visualized. During closer inspection, the missing anterio-inferior contour of the $\mathrm{C} 2$ vertebral body was observed, suggesting what turned out to be a tumourrelated erosion of a part of $\mathrm{C} 2$.

By the time the patient underwent MRI examination in December 2014, he had to wear an orthopedic collar and took $100 \mathrm{mg}$ of Tramadol 3 times a day for pain relief. The cervical spine MRI revealed a pathological mass of high contrast uptake, originating from the vertebral body and arch of C2, and measuring $30 \times 41 \times 33 \mathrm{~mm}$. The mass protruded into the retropharyngeal space as well as spinal canal.

Address for correspondence: Paweł Szmygin, Neurosurgery and Paediatric Neurosurgery Department, Clinical Hospital SPSK4 in Lublin

E-mail: pawelszmygin@wp.pl

Received: 22 April 2016; accepted: 10 November 2016
The patient was referred to a neurosurgeon who qualyfied the patient for an operation for posterior occipito-cervical stabilization, $\mathrm{C} 1$ and $\mathrm{C} 2$ laminectomy, and biopsy of the tumour. The surgery was performed in January 2015. A C0-C3-C4 posterior stabilization was chosen, 2 titanium rods were fixed with screws to the occipital bone and lateral masses of $\mathrm{C} 3$ and $\mathrm{C} 4$ cervical vertebrae. The patient stated complete resolution of his pain. Negative consequence of the surgery was limited to range of neck mobility and difficulties in opening the mouth widely. The biopsy analysis identified a giant cell bone tumour.

Beginning in March 2015, the patient was treated with 6 Denosumab injections, delivered at one-month intervals. The control MRI showed no signs of remission or progression of the tumour.

In December 2015, the patient was admitted to the Neurosurgery Department to undergo an anterior transoral transpharyngeal resection of the tumour. The surgical approach turned out to be impossible due to the limited opening of the mouth.

In February 2016, the patient was readmitted and consented to the neurosurgeon's plan to perform the resection through a mandibulotomy, with the support of an ENT-surgeon. During the surgery, sufficient opening of the mouth was obtained and the mandible was spared. The patient was intubated through the nose. A linear incision of the posterior pharyngeal wall was made, visualizing $\mathrm{C} 1, \mathrm{C} 2$ and the superior aspect of $\mathrm{C} 3$. The anterior arch of the atlas and C2 vertebral body with the dens were resected with a drill and Kerrison rongeur. The bone appeared to be healthy. The lower portion of $\mathrm{C} 2$, the $\mathrm{C} 2 / \mathrm{C} 3$ intervertebral space and C3 vertebral body were infiltrated with the tumour - the tissue was soft, grayish, and bled when removed with a punch forceps. A $40 \mathrm{~mm}$ cage was implanted between the clivus and the remainder of the $\mathrm{C} 3$ vertebral body.

After the surgery, the patient left the operating room intubated to ensure patent airways in case of swelling of the operated area. On the second post-operative day, the patient was extubated and showed no difficulties while breathing. However, he remained on enteral nutrition administered through the nosogastric tube for another 3 days. The patient's overall state quickly improved and patient was discharged from hospital on the $10^{\text {th }}$ post-operative day. He had no pain in the neck, the postoperative wound was healing well, difficulties in swallowing were gradually improving. 


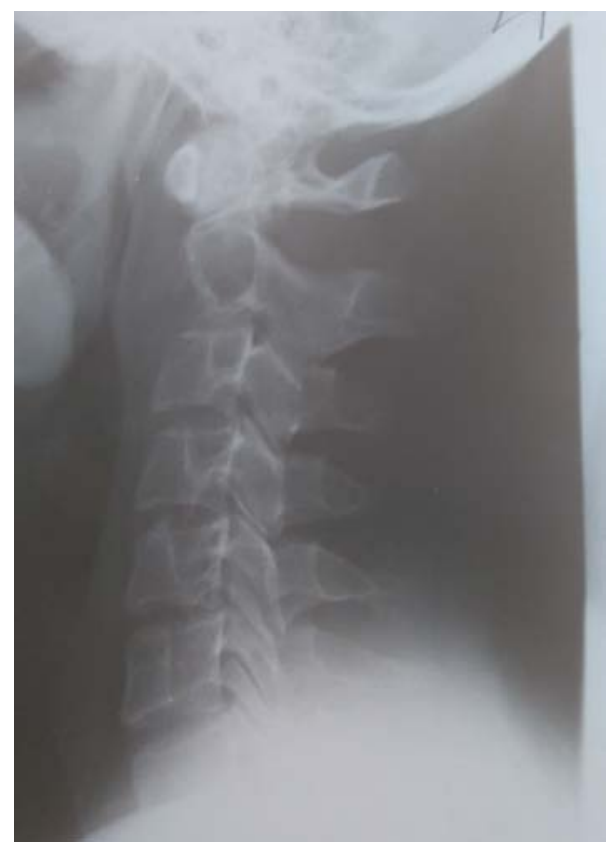

Figure 1. Lateral cervical spine x-ray demonstrating erosion of the lower front portion of C2 vertebral body

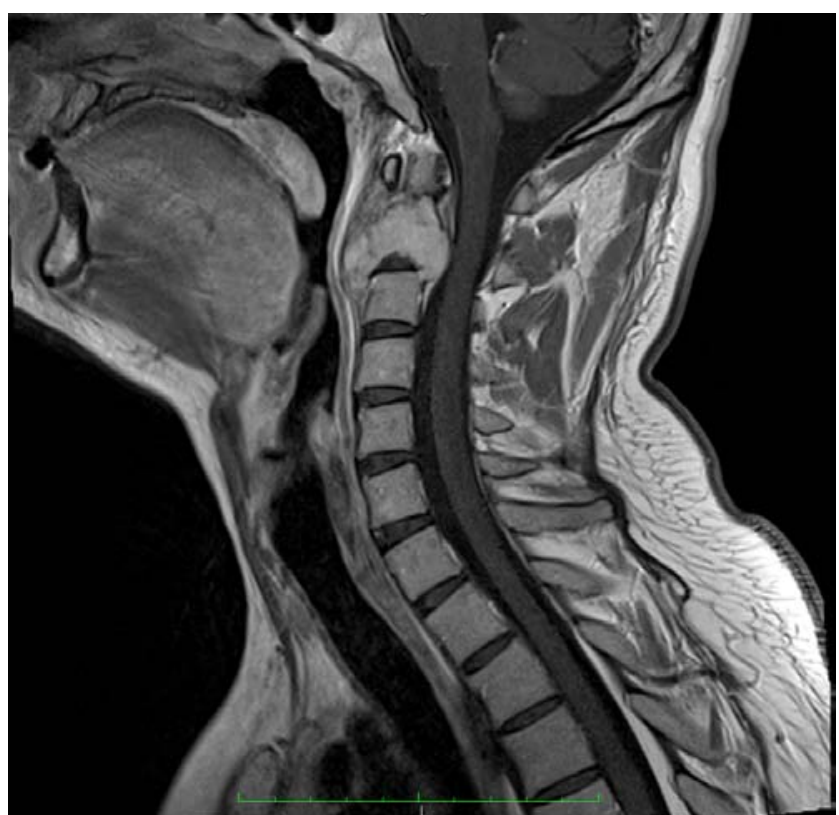

Figure 2. T1-weighted cervical spine MRI preoperative, sagittal and axial cut, a pathological mass of intense contrast enhancement originating from the vertebral body and arch of $\mathrm{C} 2$, measuring $30 \times 41 \times 33 \mathrm{~mm}$ and infiltrating odontoid. The mass protrudes into the retropharyngeal space and spinal canal

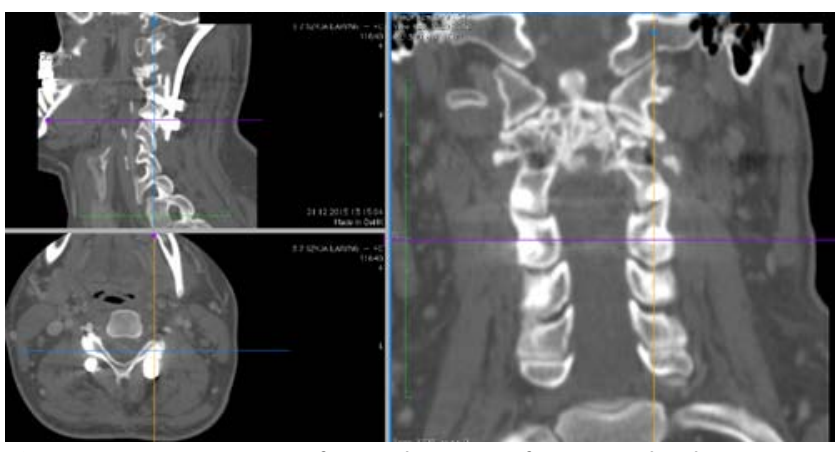

Figure 3. 3D reconstruction of cervical spine $\mathrm{CT}$ after a $\mathrm{C} 1$ and $\mathrm{C} 2$ laminectomy, posterior $\mathrm{CO}-\mathrm{C} 3-\mathrm{C} 4$ occipito-cervical stabilization and biopsy of the tumour

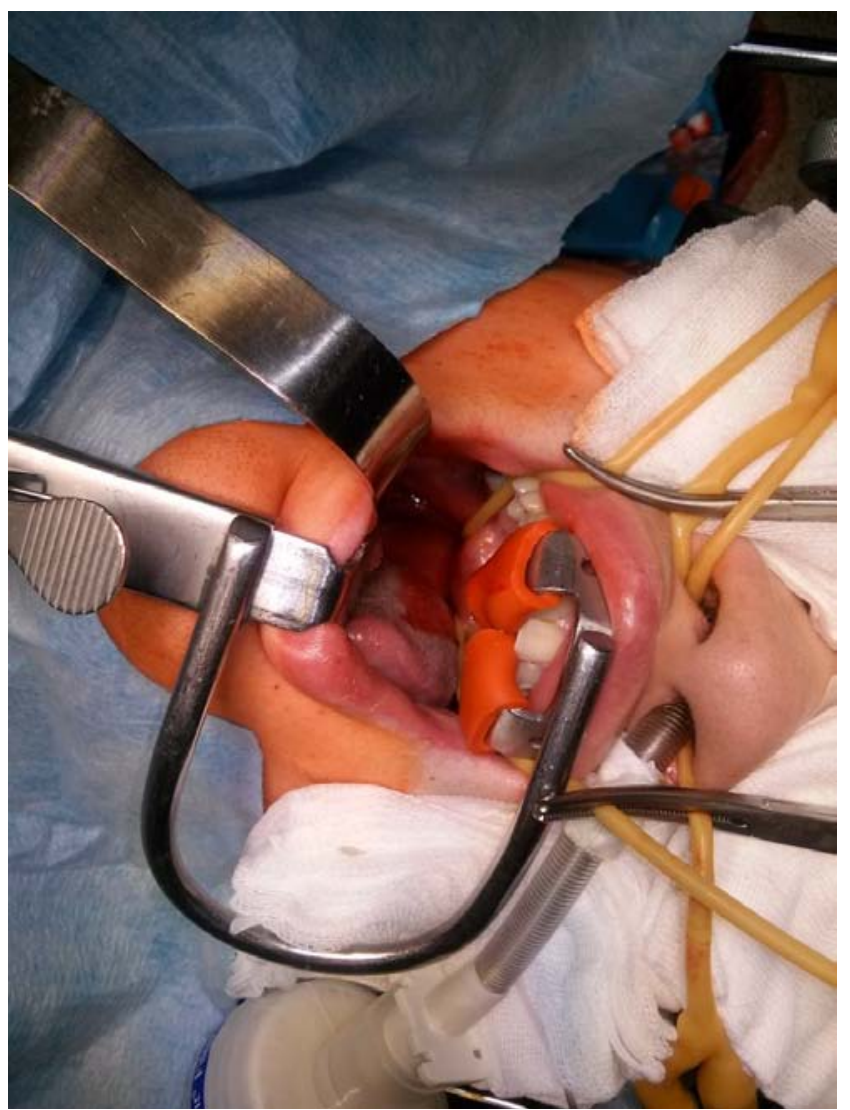

Figure 4. Operation field, anterior aspect of transoral approach, mandible and upper lip retracted

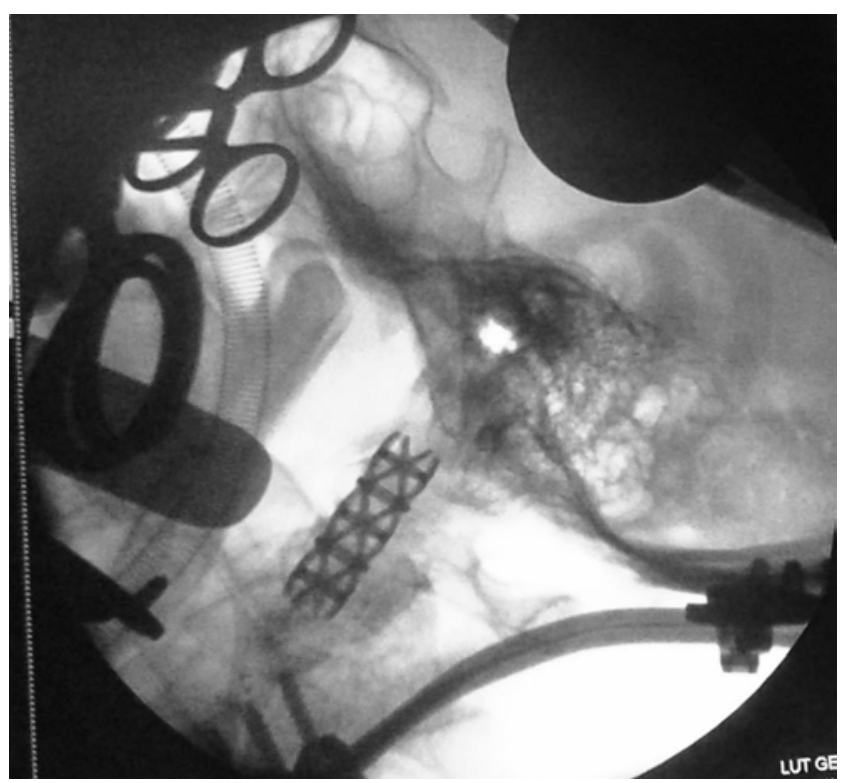

Figure 5. Intraoperative lateral cut fluoroscopy, C2 vertebral body and odontoid process replaced with a titanium cage

\section{DISCUSSION}

First described in 1818 by Cooper [1], Giant-cell tumour (GCT) is a rare neoplasm of the bone, representing $5 \%$ of all primary bone tumours [2] and $20 \%$ of benign bone tumours [3]. Patients are usually diagnosed with giant cell tumour in the third or fourth decade of life and more frequently among 
women [4]. Histologically the tumour is characterized by proliferation of mononuclear stromal cells and abundant multi-nucleated giant osteoclast-like cells evenly distributed within the tumour tissue. They arise form an osteoclastmonocyte lineage, characterized by CD68 marker expression [5]. Malignant transformation occurs in $1-9 \%$ of cases [6, $7,8,9]$. GCTs tend to grow slowly, but local recurrence has been reported to be as high as 50\% [10]. Distant metastasis of GCT is reported to be around $2-9 \%$, predominantly into the lung [11].

Radiologically GCT may resemble aneurysmal bone cyst, brown tumour of hyperparathyroidism, osteoid osetoma or plasmocytoma; therefore, a careful differential diagnosis is necessary $[6,12]$.

Surgical treatment may be primarily radical (wide resection) or may consist in intralesional curettage. The former approach eliminates the possibility of recurrence, but can impair the function of the affected organ and necessitate reconstruction. In a study presented by Seon Chun et al, gross total resection proved to be the best surgical protocol with no recurrence in follow-up, as opposed to subtotal removal with recurrence rate of $54 \%$ (average recurrence free period - 14 months) [13].

Although radiotherapy is sometimes used as alternative or complementary treatment, some authors suggest that it is ineffective or could cause malignant transformation of giant cell tumour $[4,14,15]$. Other possible adjuvant therapies include: cryotherapy, pre-operative embolization, bone cement injections, biphosphonates and denosumab. Although, not extensively documented, the application of these methods has shown some encouraging results $[16,17$, $18,5]$.

Giant cell tumour occurs most typically (90\% of cases) in peri-articular epiphyseal locations of the long bones, in decreasing order: the distal femur, the proximal tibia, the distal radius, and the sacrum [15]. According to a study performed by the Mayo Clinic (Rochester, Minnesota, USA), up to $6.5 \%$ of GCTs develop in the spine and account for $7-10 \%$ of primary spinal tumours, the sacral bone being the site most often affected area [19]. The upper cervical spine is a very rare location for this neoplasm, reported to be less than $1 \%$ of GCT cases $[20,21,9,22]$.

\section{CONCLUSIONS}

For GCT in the upper cervical spine region, a submandibular retropharyngeal approach is recommended for optimal exposure of the anterior cervical spine, from the craniovertebral junction up to $\mathrm{C} 4$. On the other hand, the transoral approach is suitable for biopsy and limited excisions of the lesion. An injury of the ninth and tenth cranial nerves and of the pharynx may occur, especially in the previous surgical approach, causing transient deglutition impairment [23].

\section{REFERENCES}

1. Turcotte RE. Giant cell TUMOUR of bone. Orthop Clin North Am. 2006; 37(1): 35-51

2. Eckardt JJ, Grogan TJ. Giant cell tumor of bone. Clin Orthop Relat Res. 1986; 204(2): 45-58.

3. McGrath PJ. Giant-cell tumour of bone: an analysis of fifty-two cases. J Bone Joint Surg Br. 1972; 54(2): 216-29.

4. Hart RA, Boriani S, Biagini R, Currier B, Weinstein JN. A system for surgical staging and management of spine tumors. A clinical outcome study of giant cell TUMOURs of the spine. Spine (Phila Pa 1976) 1997; 22: 1773-1782. discussion 1783.

5. Thomas DM, Skubitz T. Giant-cell tumour of bone. Curr Opin Oncol. 2009; 21: 338-344.

6. Bertoni F, Present D, Sudanese A, Baldini N, Bacchini P, Campanacci M. Giant-cell tumor of bone with pulmonary metastases. Six case reports and a review of the literature. Clin Orthop Relat Res. 1988; 237(2): 275-85.

7. Pai SB, Lalitha RM, Prasad K, Rao SG, Harish K. Giant cell tumor of the temporal bone-a case report. BMC Ear Nose Throat Disord. 2005; 5: 8.

8. Siebenrock KA, Unni KK, Rock MG. Giant-cell tumour of bone metastasising to the lungs. A long-term follow-up. J Bone Joint Surg Br. 1998; 80(1): 43-7.

9. Werner, M. Giant cell tumour of bone: morphological, biological and histogenetical aspects. Springer-Verlag. 2006; 30: 484-489.

10. Muheremu A, Niu X. Pulmonary metastasis of giant cell tumor of bones. World J Surg Oncol. 2014; 12: 261.

11. Lackman RD, Khoury LD, Esmail A, Donthineni-Rao R. The treatment of sacral giant-cell tumours by serial arterial embolisation. J Bone Joint Surg Br. 2002; 84: 873-877.

12. Hudson T M. Fluid levels in aneurysmal bone cysts: a CT feature. AJR Am J Roentgenol. 1984; 142(5): 1001-1004.

13. Seon Chun K, Wonik C, Ung-Kyu C, Sang Min Y. Clinical Outcome of Treatment for Patients with Giant Cell Tumor in Spine. J Korean Neurosurg Soc. 2015 Sep; 58(3): 248-253.

14. Ozaki T, Liljenqvist U, Halm H, Hillmann A, Gosheger G, Winkelmann W. Giant cell tumor of the spine. Clin Orthop Relat Res. 2002; 401: 194-201.

15. Sanjay BK, Sim FH, Unni KK, McLeod RA, Klassen RA. Giant-cell tumours of the spine. J Bone Joint Surg Br. 1993;75:148-154.

16. Gille O, Oliveira Bde A, Guerin P, Lepreux S, Richez C, Vital JM. Regression of giant cell tumor of the cervical spine with bisphosphonate as single therapy. Spine (Phila Pa 1976) 2012; 37: E396-E399.

17. Lee CG, Kim SH, Kim DM, Kim SW. Giant cell tumor of upper thoracic spine. J Korean Neurosurg Soc. 2014; 55: 167-169.

18. Marcove RC, Lyden JP, Huvos AG, Bullough PB. Giant-cell tumors treated by cryosurgery. A report of twenty-five cases. J Bone Joint Surg Am. 1973; 55: 1633-1644.

19. Boriani S, Bandiera S, Casadei R, Boriani L, Donthineni R, Gasbarrini A, et al. Giant cell tumor of the mobile spine: A review of 49 cases. Spine (Phila Pa 1976) 2012; 37: E37-45.

20. Dahlin D C. Giant-cell tumor of vertebrae above the sacrum: a review of 31 cases. Cancer. 1977; 39(3): 1350-1356.

21. Lopes A A, Cassidy J D, Yong-Hing K. Giant-cell tumour in the cervical spine: a case report. J Can Chiropr Assoc. 1989; 33(22): 76-81.

22. Santiago N M, Ferreira A, Otta G, et al. Giant cell tumor of the cervical spine: review and case report. Arq Bras Neurocir. 2012; 31(4): 245-248.

23. Balke M, Schremper L, Gebert C, et al. Giant cell tumor of bone: treatment and outcome of 214 cases. J Cancer Res Clin Oncol. 2008; 134(9): 969-978. 